\title{
Cultural biodiversity unpacked, separating discourse from practice
}

\author{
Mariagiulia Mariani $^{1}\left[\right.$ D $\cdot$ Claire Cerdan $^{1} \cdot$ Iuri Peri $^{2}$
}

Accepted: 26 November 2021 / Published online: 25 January 2022

(c) The Author(s) 2022

\begin{abstract}
In this article, we question to what extent origin-food labels, namely Geographical Indications (GIs) and Slow Food Presidia, may effectively account for cultural biodiversity (CB). Building on Foucault's discourse theory, we question how the Slow Food movement and GI promoters have developed their own discourse and practice on CB, how these discourses contrast, and how they inform projects. Focusing on the practices to cultivate the microbiological life of three origin labeled cheeses (from France and Italy), we have revealed the gap between these institutional discourses and what happens on the ground. We argue that how actors' relationships in the marketplace unfold, from public authorities to the collectives of producers to consumers, may threaten the effects that these experiences of alternative food productions may have in the defense of biodiversity, causing, for instance, the loss of diversity of the invisible microbial ecosystems of artisan raw milk cheese. However, we conclude that, despite limitations, the mediatized institutional narrative on CB can amplify the political voice of local actors by fostering community and social relationships between the farmers.
\end{abstract}

Keywords Geographical Indications · Slow Food · Starters · Cultural Biodiversity · Food Heritage · Cheese

$\begin{array}{ll}\text { Abbreviations } \\ C A P & \text { Common Agriculture Policy } \\ C B & \text { Cultural biodiversity } \\ C B D & \text { Convention on Biological Diversity } \\ C N A O L & \begin{array}{l}\text { Conseil national des appellations d'origine } \\ \text { laitières }\end{array} \\ & \text { European Union } \\ \text { FU } & \text { United Nations Food and Agriculture } \\ & \begin{array}{l}\text { Organization } \\ \text { Geographical Indication }\end{array} \\ \text { GMO } & \begin{array}{l}\text { Genetically modified organism } \\ N G O\end{array} \\ \text { Non-governmental organization } \\ \text { OFS } & \text { Origin food schemes } \\ \text { SFFB } & \text { Slow Food Foundation for Biodiversity } \\ \text { UNESCO } & \text { United Nations Educational, Scientific and } \\ & \text { Cultural Organization }\end{array}$

Mariagiulia Mariani

mariagiuliam@gmail.com

1 UMR Innovation, CIRAD/Montpellier SupAgro, 73 rue Jean-François Breton, 34398 Montpellier Cedex 5, France

2 Di3A, Università di Catania, Via Santa Sofia 100, 95123 Catania, Italy

\section{Introduction}

Biodiversity is a ubiquitous and evocative term raising at times alarmism at its loss and at other times excitement for its salvation power. The discourse on biodiversity is not limited to wild species but implicates agriculture as well, which is seen on one hand as a destroyer of biodiversity owing to agriculture intensification and on the other as a conservator of biodiversity in the case of sustainable agriculture (EC 2011; McLaughlin and Mineau 1995). Physical and social scientists, policy makers, and civil society share a complex, controversial, and changing narrative (Gustafsson 2013; Orlove and Brush 1996; Thomas 2015).

Origin food schemes (OFS), such as the state-driven Geographical Indication (GI) system, which protects place-based food names, attach the value of a product to a particular place. The product uniqueness and added value depends on the local cultural and biological resources, often referred to in literature as terroir (Bowen 2010; Vitrolles 2011). OFS are increasingly mentioned in the debate over biodiversity, which will henceforth be referred to as cultural biodiversity $^{1}(\mathrm{CB})$ to emphasize the relevance of local knowledge and practices in the management of agricultural biological resources (Bérard and Marchenay 2006; King and

\footnotetext{
1 Authors have named such biological diversity framed and nurtured by human practices in different ways: agro-biodiversity, ethno-biodiversity, biocultural diversity.
} 
Eyzaguirre 1999). However, this emergence of CB in food policy debates corresponds to different rationales, e.g. the economic benefits of its defense (Belletti et al. 2017; MarieVivien et al. 2014; Vandecandelaere et al. 2009), territorial development based on a common heritage (Grasseni 2011; Siniscalchi 2013; van Caenegem and Taylor 2017), and the protection of indigenous knowledge in the Global South (Blakeney 2013; Roussel and Verdeaux 2007).

GIs are primarily promoted for their potential "to protect local food cultures, offer a stronger quality guarantee to consumers", and provide opportunities for value-added agriculture (Bowen 2015, p. 16) and not as legal tools defending CB (Giovannucci et al. 2009; Thévenod-Mottet 2010). However, over the last two decades, European governments have debated ${ }^{2}$ and implicitly embedded CB in the GI system, echoing the consumers' perception of GIs as traditional and environmentally friendly (Belletti et al. 2015). Despite the risk of sanctions due to protectionism, GIs have also been considered for the possible application of article 8(j) of the Convention on Biological Diversity (CBD), concerning the defense of cultural resources coupled with biological ones (Boisvert and Caron 2010; Curci 2010). On the ground, European GI product specifications, which define mandatory production practices and which increasingly include concerns about $\mathrm{CB}$, provide a link between food quality and its origin (Bérard et al. 2005). This corresponds to the need for conservation of specific resources over time and/or to a marketing strategy addressing growing consumer concerns (Belletti et al. 2015; Isla and Wallet 2010).

On the other hand, social movements and NGOs have also developed strategies to contain the erosion of $\mathrm{CB}$ (Escobar 1998; Holmes 2015). Since 1999, the international Slow Food movement-born in Italy to combat the industrial uniformity of tastes-has launched more than 500 projects, called Presidia, with the declared aim of saving native breeds, vegetable varieties, and artisanal products at risk of disappearing by promoting them to consumers. The movement progressively shifted its focus from taste to ethics, questioning the environmental, social, and economic sustainability of the production process (Lotti 2010). Biodiversity - composed of domesticated landraces, traditional knowledge, and landscapes_-became a keyword and core activity of the Slow Food Foundation for Biodiversity (SFFB). If at present these ideas coincide with those of other environmental associations and public policies, Slow Food was the first to introduce them in Italy using vocabulary originating from the military sphere ${ }^{3}$ and blended with

\footnotetext{
${ }^{2}$ See the June 222009 Regions Committee, the 2006 Grenelle de l'environment (Boisvert and Caron 2010), and the 2013 French National Assembly debate (Chabrol and Marie-Vivien 2014).

3 Presidium is from the Latin praesidium meaning "defense.".
}

biblical images: the salvative power of biodiversity, the Ark of Taste, the moral goodness of artisan food and producers, the trust which shapes the supporters' community (Leitch 2003; Siniscalchi 2013).

Despite being promoted by different institutions (states and civil society), both the GI system and Slow Food are market tools with associated values that have hence developed institutional discourses on $\mathrm{CB}$ and specific standards for producers. However, what are the outputs of OFS in the management of CB? Do concrete experiences of OFS correspond to what institutional discourses contend, or is there a gap between what OFS say and do? These questions have been partially answered by an emerging body of research in geography, political ecology, and agro-economy that explores logic and tools that integrate the natural world into markets, i.e. the commodification of nature, asking if it is possible to conserve biodiversity without supporting the neoliberal capitalism that considers nature on the basis of its value (Castree 2008; Guthman 2007; Holmes 2015). For instance, authors have assessed the widespread phenomenon of ecosystem services, criticizing the limits of an "ontology of nature" (Escobar 1998) based on the dominant market paradigm (Barnaud and Antona 2014; Buizer et al. 2016; Dedeurwaerdere 2014). Within this frame, several authors have emphasized the inherent risk of market appropriation of OFS (Bowen and De Master 2011; Goodman and DuPuis 2002; Grasseni 2011), while others have highlighted new forms of environmental governance, which include local (and indigenous) communities, consumers and civil society, corporations, and transnational institutions (Liverman 2004; Morris and Kirwan 2011; Plieninger et al. 2018).

However, the existing literature does not establish if there is a gap between the discourse on CB provided by OFS and the underlying practices. Moreover, there is a need for a critical assessment of the outputs of different OFS (driven by states or social movements) as cultural and environmental tools. Thus, drawing on the discursive perspective outlined by Escobar's (1998) reading of Foucault (1980) and more recent analyses (Montenegro de Witt 2016; Nazarea 2005; Nazarea et al. 2013), this paper explores the contested relationship between institutional discourses on $\mathrm{CB}$ and meaningful everyday practices of local actors, overcoming a rhetoric of joint goals and vision. By doing so, this paper aims to explore the possibility of OFS allowing local communities to engage with the concept of $\mathrm{CB}$ in political arenas.

We illustrate our point through a study of the management of microbiodiversity of origin cheese. Cheese production systems link knowledge and practices to all the categories of life: ecosystems, vegetables, animals, and microorganisms (Bérard and Marchenay 2006). Moreover, practices related to microbiodiversity are the fulcrum of recent debates on the GI systems and Slow Food. 
Fig. 1 Evolution in the political and scientific consideration of biodiversity

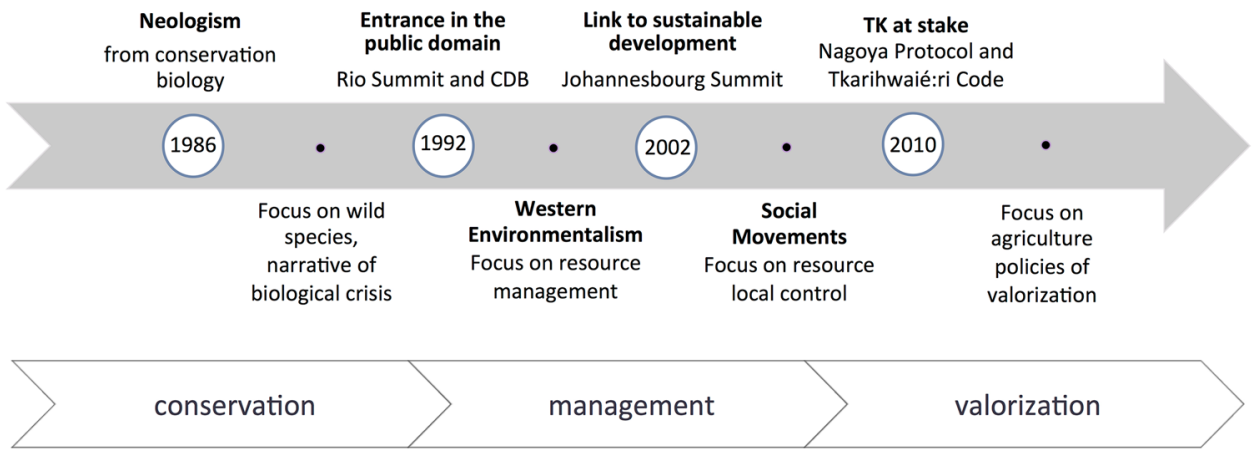

First, we will explore the emergence of $\mathrm{CB}$ as a political discourse, specifically in the domain of origin cheese. Next, we will confront how the GI system and Slow Food mobilize CB, looking at cheese microbiodiversity. Then, we will analyze evidence from three case studies of cheeses recognized as GIs and/or Presidia-Piacentinu Ennese, OssauIraty, Béarn mountain cheese-in relation to their codified and tacit practices concerning microbiodiversity. Finally, we will discuss the reasons for the gaps between discourses and everyday practices in relation to CB in both OFS types.

\section{Biodiversity as a political discourse}

This paper is built on a discoursive perspective rejecting the use of the term "biodiversity" as both a theory and a reality (Castree 2008; Escobar 1998; Montenegro de Wit 2016; Takacs 1996). This theoretical approach is rooted in Foucault's (1971) notion of discoursive practices defined as different from everyday speech and pertaining to reasoning. Every discourse emerges and changes in function to its political use and determines what can be thought and said, and what cannot, in a specific moment. As Foucault (1971) contended, in different "episteme", i.e. systems of knowledge and truth, things are perceived and classified differently. Far from being culturally neutral, every discourse generates exclusion through systems of truth defined by influential institutions and "experts" (Dreyfus and Rabinow 1982).

Following Foucault, beyond its physical content, biodiversity can be identified as a social construct, or in Escobar's (1998, p. 54) words, a "historically produced discourse," framed by heterogenous interests. For instance, Montenegro de Wit (2016, p. 638) argued that "agrobiodiversity needs to be understood in political and agroecologial terms: not just as something that exists but that is created and sustained," i.e. something that is used and experienced by people. Escobar (1998, p. 55) argued that if biodiversity is "the construct around which a complex discourse of nature is being deployed," hence the discourse on biodiversity fashions a new relationship between nature and society.
According to this perspective, the discourse on biodiversity depends on who controls it and whose knowledge is considered within a setting of asymmetries of power. For instance, Shiva (1993) observed that one of the consequences of the growing use of scientific data and language in the discussion of biodiversity is that local knowledge is first fragmented then eradicated. Moreover, Montenegro de Wit (2016), instead of questioning if erosion of biodiversity is happening or not, argues that it depends on the question: who is assessing and why?

Biodiversity in the public arena: which ontology of nature?

Although the diversity of life is a concept as ancient as biology, only in the last 20-30 years has the term "biodiversity" appeared in the political agenda to point out how human beings can conserve life and be resilient to what environmentalists call "planetary boundaries" (Steffen et al. 2015), (Fig. 1). Policy makers and media have appropriated this concept following the 1992 Rio Earth Summit, also by means of the controversial CBD (Boisvert and Caron 2010; Lacy 1994), albeit the focus was on wildlife and reference to agrobiodiversity was absent.

Initial acknowledgment of the "genetic erosion" of biological diversity in agriculture has been recognized since the mid-1980s through ex situ conservation initiatives of food plant genetic resources. However, only in 2000 did the CBD recognize agriculture as a crucial sphere in which to protect the biological diversity of genes, species and ecosystems, and defined a work program on agriobiodiversity (CBD annex to decision V/5). Since then, the United Nations Food and Agriculture Organization (FAO) has overseen the CBD in relation to agricultural diversityand its member states have been in charge of implementing national policies. In particular, the European Union (EU) Common Agriculture Policy (CAP) is increasingly concerned about biodiversity loss in relation to unsustainable agricultural practices, promoting direct and indirect subsidies for environmentally friendly practices (Deverre and De Sainte-Marie 2008).

In 2010, the link between biodiversity and cultural diversity was formally brought into the public arena with the Declaration on Bio-Cultural Diversity aimed at strengthening 
the links between biological and cultural diversity initiatives, under the impetus of the United Nations Educational, Scientific and Cultural Organization (UNESCO). The CBD was further implemented by the Nagoya Protocol and the Tkarihwaié:ri Code of Ethical Conduct, emphasizing the importance of indigenous and local communities and knowledge in relation to biodiversity. Then, the 2014 Florence declaration provided a deeper recognition of the relevance of cultural and heritage dynamics in the maintaining and re-creation of biodiversity in European agrarian landscapes (Agnoletti and Rotherham 2015).

As suggested by Blandin (2009), these international policy texts mark a semantic shift: the concept of "nature" was substituted with "natural resources" and then with "biodiversity". This last term is used to refer to a "reality" that can be "quantitatively verified" and implies that ecosystems need correct management. Similarly, the concept of "culture" has been progressively substituted by that of "knowledge" and "knowledge management". In particular, such texts basically demand a fair sharing of the economic benefits arising from the use of indigenous resources, without questioning their market appropriation, for instance by means of intellectual property rights (IPR) (Van Overwalle 2005). Moreover, such texts affirm that local communities depend on states for the protection of genetic and cultural resources (Aubertin et al. 2007).

At the same time, the term "biodiversity" has rapidly gained acceptance among NGOs, social movements, and indigenous societies. For instance, numerous Western conservation NGOs have become influential actors in the biodiversity arena (Holmes 2015). A variety of social actors, particularly those from the biodiversity-rich regions of the world, now use this term to describe their activity (Escobar 1998).

The increasing relevance of biodiversity as a political discourse is also mirrored by the changing focus of research, shifting first from conservation biology to the protection of species or areas, and then to a management of ecosystems, including cultural dimensions, through positive protection in situ (Altieri and Merrick 1987; Bérard and Marchenay 2006; Brookfield 2001). Vast socio-economic literature has increasingly addressed CB as an asset for territorial governance and sustainable local development, able to reduce rural poverty by improving resilience and food security (Carrà 2005; Santilli 2011). Conversely, ethnographic studies recognize the primary role of local people in conservation and thus advocate for community sovereignty (Orlove and Brush 1996; Brush 1991).

This excursus shows that the concept of biodiversity has been constructed as a political discourse, splintered according to the heterogeneous actors' interest and contexts. Five analytical dimensions allow us further understanding of how different categories of actors, e.g. Western environmentalists and social movements, appropriate the concept (Descola 2011; Escobar 1998; Thomas and Boisvert 2015). The actors' understanding and practice of biodiversity may vary greatly in terms of (i) components (e.g. considering only wild resources, services, or life in general), (ii) knowledge (predominantly scientific or traditional, written or oral), (iii) value (economic, cultural, aesthetic, or subsistence), (iv) outputs (based on market or informal practices), and (v) governance (according to the varying place of transnational institutions versus local communities). However, the actors' understanding and practice of biodiversity may also largely hybridize and overlap. For instance, Escobar (1998) suggests that, although Southern NGOs criticize the Western environmental approach, they paradoxically use the same elements in reclaiming local control and contribute to the commoditization of living beings for better management of phytogenetic resources. Nevertheless, "at the margins" of such actors' networks using biodiversity to frame their projects, there is space for a counterdiscourse, and the ambiguity of the term can be inspirational for resistance and deep change of the hegemonic discourse justifying market appropriation (Nazarea 2005). Thus, biodiversity can be framed and re-framed and can be eventually used for local communities' claims.

\section{The cultural biodiversity of origin cheeses: an invisible heritage}

We can further illustrate the construction of biodiversity as a non-unitary political discourse by exploring the diverging OFS actors' appropriation of a recent discourse on cheese microbiodiversity.

From the above-mentioned rural development perspective introduced by social scientists as the dominant paradigm in rural policy-making, OFS—namely GIs and Presidia-are a strategy to recognize the added value of foods linked to, an often marginal, territory and its local know-how (Bowen and De Master 2011; Grasseni 2011). The link between local resources and an increased cultural, economic, and environmental added value depends on a process of "heritage making" that comprises the selection, activation, and promotion of biocultural resources following a multi-stakeholder negotiation (Belletti and Marescotti 2011; Biénabe et al. 2009). Selected relevant practices are codified in specifications to frame their variability across producers and in time. For instance, in the case of origin cheese, breeders' knowledge and environmental management practices enhance the link with the place of origin that make cheeses unique and consumers willing to pay a premium (Bérard et al. 2005).

In this process of "heritage making", the microbiology of cheese becomes a crucial indicator of CB. In fact, the $\mathrm{CB}$ underlying origin cheese results from shared (cultural) farming or processing practices of biological resources, "in 
a form that consumers can taste" (Percival and Percival 2017 , p. 16). This includes the diversity of microorganisms (lactic bacteria, yeasts and molds) that influence the terroir, understood as the "taste of place" (Trubeck 2008), and varies across regions and farms. Strategies and practices of selecting microbes are crucial, as "[c]ultivating microbes is the very essence of almost all cheesemaking" (Percival and Percival 2017, p. 30).

Studies in microbiology have shown that farmers' practices influence the microbiodiversity of cheese, from grazing management and fertilization (Plantureux et al. 2005; Frétin et al. 2018), to the choice of farming native breeds adapted to a territory, to the cheesemaking practices, such as "back slopping" whey cultures, ${ }^{4}$ and the choice of rennet. In particular, wooden tools, such as vats (Bérard et al. 2016) and ripening shelves (Lortal et al. 2014), have been identified as crucial in the definition of cheese microbial ecosystems. Conversely, other practices, e.g. pasteurization, are meant to reduce the native microflora of milk and to replace it with a non-native one through the inoculation of selected lactic bacteria (starters) and ripening cultures. Thus, pasteurization undermines biodiversity (Montel et al. 2014) and its related cultural value, exemplified by the highly publicized case about the possible authorization of pasteurization in the Normandie Camembert GI (De Sainte-Marie et al. 2020). Moreover, since the 1970s, selected cultures have increasingly influenced the cheesemaking techniques and tastes of both industrial and origin cheeses (Casalta et al. 2009; Feutry et al. 2016). A limited number of companies produce standardized cultures that are substituted for the unique microbial terroir in constant evolution in each dairy (Rai and Bai 2015).

Despite this crucial role, the "invisible" microflora of cheese has been largely neglected by the media and origin cheese advocates until recently because of fears of microorganisms among the general public. In recent years however, the use or rejection of commercial cultures is becoming a popular topic outside the scientific world (Asher 2016; Percival and Percival 2017). New-wave cheesemakers are moving beyond reliance on starters, reconsidering the importance of correctly produced and managed healthy and biodiverse milk. Several producers are reconsidering the risks that the over-reliance on starters poses for the farmhouse cheese industry. Reflecting this new awareness, GI producer organizations and Slow Food have acknowledged that the use of commercial cultures dominates the food quality attributes responsible for product differentiation. Consequently, microbiodiversity management practices have been

\footnotetext{
${ }^{4}$ The "back slopping" technique consists in the inoculation of whey selected from the previous day's curd to enhance the acidification process.
}

codified into the specifications of several OFS cheeses to different degrees in the last decade, as we will examine further.

The remainder of the paper proceeds by presenting our methodology and exploring institutional discourses on cheese microbiodiversity within the GI system and Slow Food. Then, we analyze evidence from three OFS cheeses in relation to their codified and tacit practices regarding microbiodiversity. In conclusion, we discuss how our findings might reveal and explain gaps between discourses and practices.

\section{Methods}

We selected three OFS that are at the forefront of practices favoring cheese microbiodiversity and illustrate complementary points by representing the diversity of trajectories of OFS driven by state or civil society: (i) the case of Piacentinu Ennese highlights differences in the communication strategy of a Presidium and a GI that share the same specifications; (ii) Ossau-Iraty product specifications have changed following emerging concerns or power relations among the GI stakeholders; (iii) Béarn mountain cheese Presidium is a symbol of the Slow Food campaign against starters.

The analysis below is the result of ethnographic research conducted between 2014 and 2017, comprising in-depth interviews, participant observation, and secondary data analysis of communication and legal material. We visited several sites in Italy: Piemonte, headquarters of Slow Food and the location of biennial international events such as Terra Madre-Salone del Gusto and Cheese, specifically on raw milk cheeses; and Sicily, where Piacentinu Ennese is produced. Moreover, we performed site visits in Béarn, France, where the Béarn mountain cheese and Ossau-Iraty are produced.

Fieldwork in Sicily was conducted for six months over 2014, 2015, and 2016. We visited six farms and held ten semi-structured interviews with the Piacentinu Ennese GI and Presidium producers, and non-OFS producers. Moreover, we interviewed five employees of institutions that provided scientific and legal support for the initiation of the OFS, including local government employees, CoRFiLaC, i.e. the applied research center on Sicilian dairies hosted in Ragusa, and the University of Catania. We also actively participated in three gastronomic events and farmers' markets, and visited eight sale points for Piacentinu Ennese, including specialty cheese shops, supermarkets, and restaurants.

For the French case studies, we made site visits to Béarn in the summers of 2014, 2015, and 2016, during the mountain cheese production. We used participant observation to learn from ten cheesemakers about their understanding of and practices regarding microbiodiversity, and conducted semi-structured interviews with stakeholders. We also 
conducted three semi-structured interviews with chefs, participated in cheese festivals, and visited five cheese maturing facilities and shops.

While in Piemonte, we reviewed Slow Food and Presidia promotional material, both printed and video. We participated in ten informal tastings and taste education workshops. We co-organized a taste education workshop at Terra MadreSalone del Gusto in 2016 on the Béarn mountain cheese made without starters.

Following fieldwork, we performed a content analysis of the collected data, including the specifications of the three OFS cheeses, the legal and promotional material related to GI products (also ten websites and three blogs, such as http://elevage.megabb.com), and placed the analysis within an analytical framework. We used Foucault's notion of discourse to analyze the discourse on biodiversity developed by OFS stakeholders, and we focused on the analytical discoursive elements previously introduced: components, knowledge, value, outputs, and governance. Moving aside from the main markers of microbiodiversity emerging from the above-mentioned literature on the microbiology of cheese production systems (see Table 1), we examined the markers related to cheesemaking (milk heating treatment, milk conservation, processing tools, use of bacterial cultures, rennet, maturing) because the producers' practices surrounding these elements are at the core of contemporary public debate, receiving comparatively little attention in previous literature.

\section{Emerging institutional discourses on microbiodiversity in origin cheese}

Increasingly, various scientific and promotional materials recognize that GI cheese quality is linked to "cheese flora" and raw milk in particular (CNAOL 2018). The use of starters is increasingly addressed with the Swiss Gruyère and the Italian Parmigiano leading the debate. ${ }^{5}$ Public funding is devoted to R\&D on sensitive topics such as the dairy microbial ecosystems management (e.g. establishing local strain banks), the conservation of locally-rooted practices, and the social acceptability of GI cheese in relation to microbiodiversity. ${ }^{6}$ However, the rhetoric on the risk of raw milk and pathogen contamination is publicized to a much greater degree (West 2008).

\footnotetext{
5 Both Gruyère and Parmigiano GIs are manufactured with local whey starters.

${ }^{6}$ Since 2008, in France, the working group Réseau Mixte Technologique fromages de terroirs focuses on how the management of microbiodiversity can ensure the resilience of GI cheese systems.
}

For its part, Slow Food has been legitimizing cheese microbiodiversity in the public and gastronomic sphere since the 2001 launch of a campaign for "raw milk cheese" in countries where artisan cheesemakers suffer from the limitation of strict health regulations. In 2017, a campaign for "natural cheese", i.e. cheese free of starters, warns about the alarming loss of microbiodiversity generated by industrial standards that inhibit the growth of bacterial flora. Slow Food communication materials describe bacterial cultures as natural or indigenous, in opposition to industrial or commercial, and consider microbiodiversity responsible for good and diverse tastes. By using starters, Slow Food warns, small producers risk losing the potential to differentiate themselves.

\section{Components}

Biodiversity comprises local biological and cultural resources in both the GI system and Slow Food, and implies nature which pre-exists human activities. In this approach to the human/nature relation, nature can be destroyed by human beings and hence ought to be protected. For instance, the institute representing the 50 GIs of French dairy products $^{7}$ (French acronym CNAOL) contends that GI producers which process raw milk and use traditional cheese-making methods preserve microbiodiversity.

Cultural components predominate in Slow Food gastronomic $\mathrm{CB}$. The movement's declared mission is raising awareness of the intrinsic value and need for protection of knowledge and collective memory of a community, which grows and processes traditional food. This cultural value transcends the food itself.

Regarding the discourse on microbiodiversity, Slow Food introduced an apparently oxymoronic binome: the natural cheese and the good artisan cheesemaker. On the one hand, the natural-ness of cheeses is considered incompatible with starter inoculation. "Natural" becomes a slogan that is built on anxiety about industrial food and globalization to describe cheese that, instead, is made in harmony with nature, from astral elements (as in biodynamic wine) to microbes. On the other hand, Slow Food counters the decision of using starters as a shortcut to the demands of knowledge and time with the good choice of crafting natural cheese. Thus, nature and microorganism are ubiquitous, but must be protected.

\footnotetext{
${ }^{7}$ France is the country with the highest number of GIs on dairy products.

8 "In nature, bacteria are found in milk, on the cheesemaker's hands, on the animals' udders, in the bucket used for milking, and on wooden tools" (Slow Food 2017).
} 


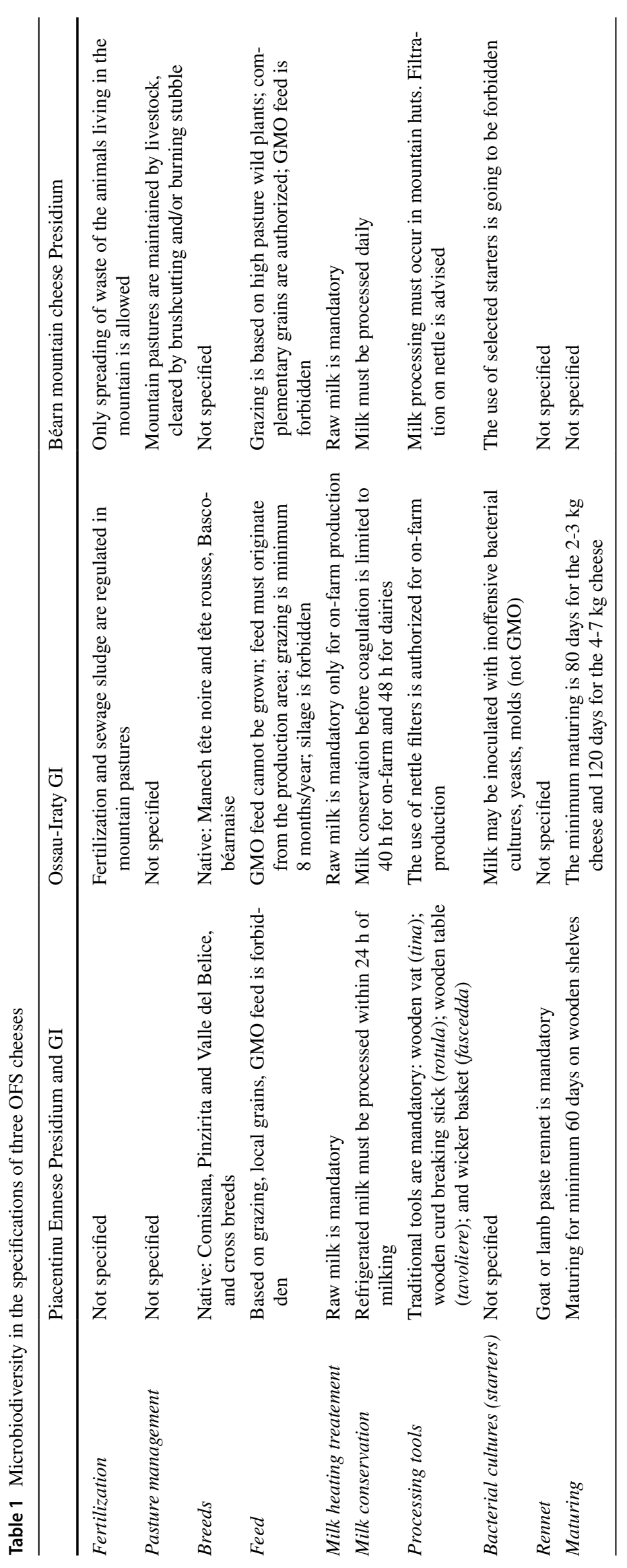




\section{Knowledge}

Both OFS are examples of conservation in situ and provide a revival of local ecological knowledge. Both legitimize practices of everyday conservation that are often implicit and beyond programmatic design, and contrast with scientific conservation initiatives financed by and benefiting industry (Graddy 2013; Nazarea 2005). For instance, CNAOL (2018) refers to the "living knowledge" of GI producers that is continuously perfected and rooted into microbiodiversity, e.g. producers are meant to modify processes with the day-to-day variations in milk and optimize milk safety while preserving the bacteria useful for cheesemaking (CNAOL 2018).

Slow Food recognizes that local ecological knowledge allows farmers and food processors to be "guardians" of plant varieties and animal breeds. Unlike seed banks or traditional knowledge museums, Slow Food calls on producers to actively engage with consumers in the battle to save $\mathrm{CB}$ because "[e]very one of us can do something, in our local area, every day. We must not dwell on what we have lost, but focus on what we can still save" (SFFB 2018).

However, the GIs and Presidia's discourse on CB mobilize scientific knowledge. GI communication materials are grounded in scientific evidence, e.g. studies proving the health benefit of cheese flora or the beneficial role of wooden cheesemaking tools in preserving the biofilm. ${ }^{9}$ For its part, Slow Food legitimizes local knowledge in the public arena, often in contrast with scientific knowledge. In other circumstances, Slow Food instead mobilizes scientific knowledge to warn about a quantifiable loss, e.g. data from the $2011 \mathrm{EC}$ Biodiversity Strategy (Slow Food 2015) and, as the case of microbiodiversity best demonstrates, acts as the authority defining which (good) CB must be pursued and protected.

\section{Value and Outputs}

Both studied OFS recognize the socio-economic value of $\mathrm{CB}$ and design a qualification process of non-market specific and common resources and attributes.

$\mathrm{CB}$ has been introduced into the GI qualification process, albeit marginally, by means of the concept of heritage, i.e. recognizing $\mathrm{CB}$ as a common good to be valued and preserved by producers' collective bodies (Bérard et al. 2005). In particular, the discourse on microbiodiversity tends to transform the unique microbiological characteristics of a cheese and the related production practices into heritage, since over 300 bacteria strains and 70 species of yeasts are responsible for unique taste and flavors. Moreover, microbiological richness is linked to health, based on its immunological power, because it protects cheese from pathogens,

$\overline{9}$ Biofilms cover wooden tools with complex microbial communities. positively interacts with the gut microbiota, and reduces atopic allergies and asthma (CNAOL 2018). Microbiodiversity is responsible for taste, quality, and added value just like the more visible forms of biodiversity.

Conversely, the qualification process designed by Slow Food is loaded with moral language and CB has become a fundamental moral attribute, together with ecological (Siniscalchi 2013) or aesthetic attributes (Miele and Murdoch 2002). Thus, CB is a crucial condition for belonging to the movement and thus for taking advantage of its distinctiveness. We find that the Slow Food discourse on CB tends to transform food into a moral good, based on a supposed risk of extinction, by simultaneously mobilizing politically subversive language and a moral discourse aimed at salvation. As MacDonald (2013, p. 98) puts it,

"Slow Food promoters have effectively adopted the vernacular of biodiversity conservation and play on the constructed value of diversity (biological and cultural), and a consequent fear of extinction, as a rhetorical strategy for justifying the protection of production practices and the lifestyles that underpin them".

In this respect, the recent attention to cheese microbiodiversity strengthens the designation of cheese as a moral good qualified as under threat. Farmers using selected cultures are accused of not being good, or not good enough for Slow Food. Conversely, the use of starters would jeopardize and threaten the Slow Food qualification strategy designing Presidia as "singular", "unique", "rare" products that cannot be substituted (Siniscalchi 2013).

\section{Governance}

Similarly, both OFS are based on the direct intervention of public institutions in the field of CB. The GI system is based on the legal protection of states, whereas Slow Food is a consumer-driven movement highly supported by European, national, and regional policies. Next, both OFS are increasingly used to govern environmental issues through a local negotiation process, e.g. the producers' definition of specifications.

In contrast to GIs, Slow Food promotes networks of farmers and consumers provided with new-although limited-agency. Slow Food emphasizes the role of small-scale producers, the 'Earth's last custodians,' in safeguarding CB more than other movements do. For instance, producers who reject the political dependence on the companies that produce starters are glorified. Moreover, Slow Food calls on consumers to engage locally and considers that the defense of CB implies a daily ethical behavior that should become viral and strengthen an alternative food community. Regarding microbiodiversity, Slow Food denounces starter as invisible to consumers because they are not listed on ingredient 
labels - this misleading behavior can be fixed through an awareness campaign.

In summary, GIs discourse insists on the healthiness and cultural value of cheese microbiodiversity, in particular raw milk cheese, as a way to develop an institutional and inclusive strategy of qualification based on common biological and cultural resources understood as heritage. Conversely, cheese microbiodiversity allows Slow Food to go a step further in its discourse on $\mathrm{CB}$, shifting from the defense of "traditional" and "endangered" food to "naturalness" as an exclusive moral value attached to food. What Slow Food alternatively omits is the constant technical management of microbiology in all the production steps-far from the claimed primary role of nature in cheesemaking-, and the reference to health is almost absent, both in terms of benefits and risks.

\section{Cultural biodiversity in action: confronting practices of the invisible}

With the aim of analyzing what occurs in the institutional discourse on CB in three selected mountain sheep cheeses recognized as GI and/or Presidia in Italy (Piacentinu Ennese) and France (Ossau-Iraty and Béarn mountain cheese), we will now consider both specifications and non-codified practices related to the management of microbiodiversity, as crucial elements for the definition of OFS quality attributes.

Piacentinu Ennese is a sheep milk cheese flavored with saffron, recognized as a GI in 2011 and as a Presidium in 2013 under the impetus of the Enna provincial government, Sicily. Studies conducted by CoRFiLaC supported by the Sicilian region characterized the cheese in relation to the use of raw milk of native breeds, traditional tools, local saffron, and a long period of maturation (Fallico et al. 2006; Carpino et al. 2010). Both OFS insist on the historical authenticity of the cheesemaking practices, although such cheese was almost forgotten before the recent OFS revival. Presidium and GI have a complementary focus: the GI insists on the uniqueness of Piacentino Ennese, whereas the Presidium focuses on the variety of wild plants that determines the milk microbiological richness. Its market is mainly local or regional, but increasingly attracting attention from niche cheese distributors from Northern Italy and France.

Ossau-Iraty is an uncooked and pressed sheep milk cheese, recognized as a GI in 1980. This GI is vast both in terms of area of production and stakeholder inclusion. It comprises cheeses produced over two territories (Basque Country and Béarn) corresponding to different production styles. Images of Pyrenees summits unify the imagery in promotional materials. The GI was initiated by industry, but the specifications have been revised to increase differentiation between farmer and industrial production and valorize local CB (e.g. the use of native breeds and local feed). Market distribution is twofold, with farmer production mainly sold at regional scale, and industrial cheese sold in supermarkets all over France.

The Béarn mountain cheese Presidium was launched in 2008 to protect the summertime cheese production in the Pyrenees and the practice of transhumance from the valleys to the mountain grazing areas. The Presidium aimed to recognize the uniqueness of the cheese quality and the environmental role of preserving the landscape. The Presidium iconography is based on transhumance, wild flora, and mountain cheesemaking huts. Direct sale and specialty cheese shops are the main marketing channels.

As already noted, each GI freely negotiates specifications on microbiodiversity in accordance with the link between quality and origin. In contrast, Slow Food allows only raw milk and prohibits starters. Table 1 illustrates the common choices in the specifications of the selected case studies regarding microbiodiversity management, in particular zootechnical and agronomic practices. The three specifications codify the preference for native breeds recognized as more adapted to local territories. Feed is highly regulated to favor the grazing lands located in the production area, and consequently farming diversity and the rural landscape. As in several other GIs, GMOs and biotechnology are unanimously considered to reduce biodiversity (Foyer 2010). However, limited attention is given to fertilization and the management of pastures. Specifications on the management of natural pastures that would strengthen the flora diversity and the milk microbiodiversity, as codified instead in the specifications of Comté cheese GI, are absent. Despite these collective challenges, actors in the selected OFS manage microbiodiversity differently along the cheesemaking process in crucial codified and tacit practices, which will be further developed.

\section{Milk production}

Despite milking being particularly relevant to determine cheese microbiology, none of the studied specifications regulate it. Mechanical milking is the general rule with cleaning practices left to individual choices. The only exception comes from the Béarn mountains, where manual milking is the most common practice, although not mandatory owing to its labor-intensiveness. Shepherds milk the herds manually as a necessary concession to the lack of milking machines, but also acknowledge its positive impact on milk microbiodiversity. As we were told by one of the rare shepherds equipped with a milking machine in the mountain pastures,

"The arrival of milking machines has spoiled milk richness. We lost some of the contact with animals, 
both visual and manual, and the possibility to check if they are healthy and their milk is good."

\section{Milk conservation}

Long milk conservation (over $12 \mathrm{~h}$ ) at low temperatures (between 3 and 8 degrees $\mathrm{C}$ ) negatively affects milk microbiodiversity (Montel et al 2014). A difficult decision on how to regulate and manage these aspects must be made in the case of raw milk cheeses, whereas it is less relevant in the case of pasteurized milk. In Ossau-Iraty, unpasteurized onfarm cheese producers are allowed to conserve milk for up to $40 \mathrm{~h}$, to allow producers a weekend break, whereas in Piacentinu Ennese the limit is $24 \mathrm{~h}$.

The case of the Béarn Presidium has been shown to be the most favorable to $\mathrm{CB}$, because it requires daily transformation. Shepherds stock milk in stainless steel containers submerged in cold river water overnight: this short time and high temperature refrigeration limits the milk microbiodiversity alteration and enhances instead the lactic bacteria development. This process is known as milk maturation. For this reason, Slow Food local leaders have opposed the electrification of the huts to preserve the cheese quality status quo, contending that "the non-refrigerated milk keeps the pasture's microbial flora, which gives it a characteristic taste" (Presidium communication material). The Presidium producers, on the other hand, have diverse opinions on this topic. For some the respect for tradition and milk quality prevails. As we were told, "we are used to coping with these natural variables, and this makes our daily work unique". For others the mechanization, simplification, and control of such tasks is preferable.

\section{Processing tools}

Processing tools are crucial in the specifications of Piacentinu Ennese, which codifies the use of wooden tools, i.e. a vat, a curd breaking stick, and a table, considered by producers and scientists to be responsible for particular sensorial features. In particular, the use of a wooden table is variable: it is considered by several interviewed cheesemakers as unnecessary and/or demanding arduous cleaning procedures. Moreover, dairies often also produce regular sheep cheese that is not recognized as a traditional specialty, and thus a stainless table is also necessary in the cheesemaking facility. As we were told: "We keep the wooden table only to show to auditors or visitors."

Beyond codified practices, much of the management of microbiodiversity is left to tacit knowledge, consolidated over generations on a collective or individual basis. This is best demonstrated by the adaptation of Béarn shepherds to a mountain environment. Certain cheesemaking materials and techniques are unique to summertime production and are intertwined with tacit management of CB. For example, we observed the use of a wooden stick to stir the curd and of nettles to filter milk and to clean tools. As a shepherd involved in the Presidium and in the Ossau-Iraty GI told us, "Nettles are so important for mountain cheese production. Picking them even helps us prevent arthritis related to manual milking! On-farm producers fought to get their full use recognized in Ossau-Iraty."

A transhumant cheesemaker writes on her facebook page about the use of copper cauldrons to heat the milk: "a copper cauldron, what an amazing living material!", implicitly confirming studies on the positive effects of copper on enzymes and microorganisms employed in cheesemaking (Pecorari et al. 2009).

\section{Milk heating treatment}

The choice of processing raw milk has been regulated in different ways: mandatory in the two Presidia, and for the onfarm Ossau-Iraty, but not for dairies. In Piacentinu Ennese we observed a polarization of several practices between onfarm producers (7) and small dairies (3). First, the Presidium and GI share the same specifications and the same leaders, and do not distinguish between pastoralist and semi-industrial production: both are included. However, based on a difference of practices on microbiodiversity, producers belonging to the two OFS are not necessarily mutually inclusive. In particular, one dairy producer has been excluded from the Presidium on the suspicion of pasteurizing milk. Conversely, the Consortium has impeded an on-farm Presidium producer to join the GI because he criticized the overrepresentation of dairy interests.

We observed the same polarization of practices in Ossau-Iraty. Whereas all on-farm producers process raw milk, industrial dairies process approximately $90 \%$ of the GI production by pasteurizing milk to increase profitability and reduce health and safety in a production chain that they don't directly control. However, increasingly, some of the dairies process a small volume of raw milk to differentiate their range of products and penetrate the market segment of on-farm producers. This variety of practices shows that OFS actors have not codified milk-heating practices in a way that would more forcefully attach CB to cheese.

\section{Bacterial cultures (starters)}

The choice of whether or not to use selected starters is probably the most controversial element of our analysis, as the most recent and publicized symbol of cheese microbiodiversity. Actors of the same OFS differently appropriate the discourse on starters leading to complementary or contradictory strategies, on an individual or collective level. 
The Ossau-Iraty webpage, despite the reference to ancestral knowledge based on sensory appreciation, explicitly recognizes the inoculation of milk with bacterial cultures, as well as molds and yeasts, as a regular practice. Starters (commonly containing Lactococcus lactis strains) are used by almost all farmers, including on-farm producers processing raw milk, to ensure homogeneous and regular cheese production and to overcome the risks of manipulating milk with insufficient levels of lactic acid bacteria (Feutry et al. 2012). Nevertheless, the GI is collectively searching for a path which is viable for both dairies and on-farm producers and guarantees a cheese with constant, common, and distinctive characteristics, e.g. through a bank for local strains. A study has assessed the use of isolated wild bacteria in selected starters to match the desired organoleptic features of Ossau-Iraty (Feutry et al. 2016). In addition, the GI has supported peer learning among producers, e.g. a fieldtrip to the Savoy region to study starters self-production techniques in local GI cheeses in 2016.

Piacentinu Ennese has implicitly regulated the use of selected starters by requiring the curding of cheese in wooden vats whose biofilm facilitates the multiplication of lactic acid bacteria and correct milk acidification, making starters less relevant (Lortal et al. 2009; Montel et al. 2014). Among on-farm producers, tacit practices related to milk fermentation play a crucial role in the cheesemaking process, although producers are scarcely aware of them. One of the most renown cheese-maker told us: "I have always processed milk and I wouldn't be able to use starters." We have observed his careful maintenance of the wooden vat that is scrubbed after use and rinsed with whey. However, the choice of allowing selected starters has been clearing the way for dairies to use selected starters to ensure the regularity of their production from different milk suppliers. Despite the concern that this practice should lead to the exclusion of semi-industrial producers from the Presidium, this has not occurred. Conversely, other Italian GI cheeses, e.g. Ragusano, another Sicilian cheese curded in a wooden vat (Licitra and Carpino 2014), and Fiore Sardo (Scintu and Piredda 2007), have prohibited the use of non-autochthonous starters, in order to enhance the link to the place of origin.

In Béarn, despite a programmatic "NO starters" rule imposed by Slow Food, only a tiny minority of cheesemakers is taking the risk of avoiding selected starters. In fact, for decades, technical training and extension services have built a narrative on the use of starters to cope with the contemporary reduction of lactic flora and to avoid cheese loss. On a collective level, Slow Food has provided a multiyear technical assistance to perfect the self-production of starters specific to each mountain hut, and has supported peer-learning experiences with other Presidia cheesemakers. Moreover, Slow Food has promoted such experimental cheeses to specialized audiences, such as during a workshop in 2016 Terra Madre-Salone del Gusto meant to introduce new practices, tastes, and values to consumers and journalists. On an individual basis, some producers are experimenting the self-production of starters, and practices such as back slopping, adding a yogurt, reducing the quantity of starters, and limiting their use in certain periods. Two cheesemakers explained their choice: "I want to be close to my production" or "I want to increase my cheese's unique taste". However, the Presidium members are not undertaking the change of production paradigm promoted by Slow Food. The goal of avoiding starters is not fully shared by local actors, divided by different perceptions of the risks and benefits of such a practice. Several Presidium members question the positive impact on taste from reducing the quantity of starters compared to the risks of decreasing the average quality of cheese produced without starters. This tension was best exemplified by a public clash of visions at the 2016 Terra Madre-Salone del Gusto between Slow Food leaders and Presidium members that has undermined the continuation of the project itself.

\section{Rennet}

In both French cases, producers use animal synthetic rennet, in a liquid form. As we were told by a shepherd, "I think nobody is producing rennet in the Pyrenees anymore. Onfarm lamb slaughtering has been prohibited and the use of self-produced rennet has been forbidden for safety reasons." Conversely, Pacentinu Ennese explicitly regulates the use of goat or lamb paste rennet, although certifying authorities do not control the origin of rennet and misuses occur. Several interviewed shepherds and cheese-makers opt for selfproduced lamb rennet paste and, by doing so, choose to use enzymes different from that used by other farms and to adapt their daily techniques to the changing coagulation power. Implicitly, this confirms studies that have demonstrated that farmstead rennet paste induces lipolysis ${ }^{10}$ and develops a variable and specific piquant taste during ripening (Scintu and Piredda 2007).

\section{Maturing}

Microbiodiversity related to cheese maturing is handled in a radically different way in the three OFS. Piacentinu Ennese specifications mandate the use of wooden shelves that positively contribute to the biofilm. However, we observed producers putting cheese under vacuum at the end of the prescribed 60 days, in order to slow down maturing, with the result of reducing final microbiodiversity and diversity of

\footnotetext{
${ }^{10}$ Lipolysis is the enzymatic process occurring during cheese maturation by which fats are broken down into fatty acids.
} 
tastes. Ossau-Iraty precisely specifies the duration of maturing, according to the cheese size, and has progressively controlled the chemical treatments of the rind common in industrial production. In Béarn mountains, although specifications do not focus on maturing, producers show a great interest in choosing how to mature their cheese, in which environmental conditions, with a growing number of producers choosing to internalize the maturing process. We were told: "I prefer to mature my own cheese, so that they are specific to my mountain saloir (maturing cave). They are unique".

\section{Governing cheese micro-biodiversity, a discoursive analysis}

Scholarship addressing the link between OFS and CB has often fallen in the dichotomy of reading OFS as market tools exploiting biocultural resources (Bowen and Zapata 2009; Guthman 2004) or as alternative paradigms of food production and consumption based on ethical and ecological values (Marsden and Smith 2005; Morris and Kirwan 2011; Murdoch et al. 2000; Plieninger et al. 2018). These approaches have failed to reveal the consequences of naming a new reality, such as $\mathrm{CB}$, and the changing gaps between discourses and practices.

Mobilizing a discoursive perspective (Escobar 1998; Montenegro de Wit 2016; Nazarea 2005), this paper investigated CB as a historical construct fitting into a network of actors and power, where the discourse on CB frame truthsin Foucault's words-, that are vague and leave gaps of interpretation and application. In this framework, our case studies of origin cheeses can be understood as contributing to the commodification of nature, through the definition of the scope of (local) initiatives of management of CB by experts (Slow Food or other scientific, economic or political institutions in charge of planning "local development"). For instance, OFS tend to define and, thus, control the management of starters, appropriating the agency of non-human agents such lactic bacteria and capitalizing on the origin cheese "natural" or "traditional" discourse. Conversely, other aspects of the studied OFS can be read instead as new forms of environmental governance, where producers representing a marginal agriculture are entitled to organize themselves to show the (often hidden) values of their products, such as the use of local breeds, grazing on and maintaining natural pastures. In other words, the goal of preserving CB declared by OFS is split according to contexts and actors. This allows us to discuss implications of such gaps in terms of knowledge management and governance of actors.

\section{Knowledge management, between social norms and personal values}

First, beyond the above-described diversity of codified practices on microbiodiversity, in reality, specifications are selected or circumvented, and tacit knowledge is adapted. Observed practices show that each OFS operator has significant room for maneuver, which is often based on a deep tacit understanding of the microbiological life of milk and cheese, and its fundamental contribution to taste, e.g. the cleaning procedures of wooden tools and maturing practices which change every day, for every cheese. These results confirm the stream of literature that provided ethnographic evidence of the abundant tacit knowledge underpinning the management of cheese microbiodiversity which have escaped codification, labeled by Paxson (2012) as "ecologies of production": cheesemakers belonging to a post-Pasteurian age are allied with microbes and cultivate them with specific practices (see also Grasseni 2011; Bowen and De Master 2014).

Next, we observed that OFS alone do not determine a change in local practices, but determine a shift toward new practices and issues, such as $\mathrm{CB}$, based on specifications and, most importantly, of individual values and goals. This is the case of the controversial ban of silage in Ossau-Iraty, of the use of wooden tools in Piacentinu Ennese, and of the mountain hut electrification in Béarn. Indeed, the discourse on $\mathrm{CB}$ works as a framework guiding the choice of the practices negotiated collectively, as Biénabe et al. (2009) already showed. We observed a common concern with a "desirable" CB, including microbiodiversity, that is reflected in individual and codified practices, as also shown by Boisvert and Caron's (2010) study on Salers and Saint-Nectaire cheese GIs. This confirms that social norms or personal values shape how people interact with the market and might be valuable change-drivers toward sustainability (Dedeurwaerdere 2014). Moreover, new concerns on CB also restore the relationship with consumers. For instance, Slow Food taste education workshops are conceived to train consumers to have a discriminating palate informed by Slow Food values, such as the importance of "tasting microbiodiversity", although this could controversially lead to eliminating practices favoring CB because they are judged as responsible for "bad" tastes (Lotti 2010; MacDonald 2013; West and Domingos 2012).

Then, our results show that gaps between OFS discourse and practice of $\mathrm{CB}$ are mainly due to diverging interests among stakeholders involved in different production systems. The connection between OFS and CB may be fragile on aspects that are hidden from consumers' view and understanding because practices are selectively shown and communicated. For instance, our analysis of Ossau-Iraty showed that the use of pasteurization is hidden from consumers' understanding by the image of mountain-based 
cheesemaking techniques. Similarly, Presidia stakeholders' strategies are controversially intertwined with $\mathrm{CB}$ values and practices. For instance, dairy producers of Piacentinu Ennese adopt the added value embedded in the Presidium to sell a variety of products including pasteurized cheese. Omissions and shortcuts hide discrepancies with the Slow Food "truth." Our results complement what other authors have already mentioned, i.e. that Slow Food's strict and redemptive discourse on biodiversity may be appropriated by actors in search of new markets and audiences, such as supermarket chains that diversify their product lines to include food with apparent high environmental and cultural value (Fonte 2006; Grasseni 2011; MacDonald 2013). Similarly, the GI system risks not being politicized enough by locals and thus failing to attach origin food to $\mathrm{CB}$ and influence local practices, becoming just a market tool (Dourand and Fournier 2017; Fonte 2008; Vitrolles 2011).

\section{From actors' governance to their governability and sovereignty}

Although both GIs and Slow Food have the potential to become policy devices for the management of $\mathrm{CB}$, mainly through the collective managing body defining specifications (particularly organized in the case of GIs), we identified governance as the main divergence between them. Public institutions at international and national levels frame GIs, whereas a social movement drives Presidia projects in a transnational network. This difference in multi-level governance determines the potential and limits of the two OFS.

Both OFS have a top-down approach in framing CB. We showed that EU policy texts justify GIs as a strategy to promote diverse agriculture in marginal areas, with an economic aim rooted on the cultural value of CB. This is why May (2013, p. 68) contends that public institutions benefit from GIs being a "political marketing tool" that transforms origin food into a "common good with limited property," the property of the OFS. Similarly, Slow Food Presidiadepending on public support-strengthen a strategy of regional development based on gastronomy and tourism, and foster the valorization of "made in Italy" specialties, by attaching and promoting a "moral superiority" to "idealized representations" of the "Italian way" in food, as already suggested by MacDonald (2013). ${ }^{11}$ Moreover, the governance

\footnotetext{
11 For instance, the president of Parmigiano Reggiano GI-the most traded Italian cheese in the world-presented the GI decennial experience of self-production of whey starters at the launch of the campaign for "natural cheese" in Cheese 2017. This experience was presented to an international cheesemakers' audience as a generalizable practice without considering that Parmigiano is a hard-cooked cheese that makes the use of self-produced whey starters easily possible, but this does not apply to a worldwide diversity of cheese styles.
}

of Slow Food is similar to a "pastoral power" (Foucault 1981) where-as the Foucauldian "shepherd"-Slow Food has a specific knowledge of each "sheep" (i.e. the Presidia members) and is responsible for their wellbeing, merits, and faults. In exchange for that, sheep follow the shepherd's rules as an end in itself and with controversial appropriation.

In this perspective, OFS discourses on CB can thus be understood as "technology of governmentality" (Bendix and Hafstein 2009, p. 7; Foucault 1991), where the defining authority is the institution that is teaching from outside about how to address CB: providing scientific evidence, standards, measurable goals, and moral criteria. This implies that $\mathrm{CB}$ stops being a common good owned by the humankind and becomes something that states are entitled to manage (Aubertin et al. 2007) or to outsource. In this sense, the process of transforming biocultural resources into $\mathrm{CB}$, and then into heritage, is a political act of government. ${ }^{12}$

However, our results also showed that Slow Food has a two-headed discourse. Besides fostering regional food heritage, Slow Food also underlines the value of individual progressive choices that represent the niche of a niche, i.e. the rare artisanal cheesemakers that are experimenting with their often risky strategy to increase the uniqueness of their farmstead cheese, in a more complex "ecology of production", in Paxson's (2012) words. Slow Food thus provides the justification and resonance for change, an innovation in progress, i.e. the renaissance of natural cheeses. In the discoursive arena shaped by the movement, positively dealing with microorganisms becomes an alternative to mainstream practices and regulations that minimize the positive interactions between humans and other (microscopic) living beings and increase dependency to industry. In this sense, we can refer to the Slow Food discourse on CB as "technology of sovereignty" (Hafstein and Skrydstrup 2017), providing public legitimization of tacit practices on starters, but also of defective cheeses, the promotion of collective or peerto-peer learning, the creation of spaces for experimenting innovative practices, including spaces for producers' resistance and contestation of the official Slow Food voice. To sum up, Slow Food transforms cheesemakers into political subjects entitled to make claims.

\section{Conclusion}

In this article, we explored the dilemma of whether a discourse on $\mathrm{CB}$ in OFS allows local communities to make political claims and appropriate innovative environmental

\footnotetext{
12 This echoes Latour's (1987) connection between the need of national discipline and the establishment of hygiene and microbial management as issues of French public safety (Grasseni 2017).
} 
practices or, alternatively, it paves the way for market or political capture. This paper reversed the question with a discoursive approach and explored the performative power of $\mathrm{CB}$ in specific geographical and political contexts. This allows recognition of the-often hidden-market value given to origin food and contributes to the debate on the political potential of OFS, by seeing CB alternatively as technology of governability or sovereignty. A comparison based on three origin cheeses recognized as a Slow Food Presidium and/or a GI, in France and in Italy, illustrates differences and gaps opened by diverse discourses on CB.

The findings in this paper demonstrate that both the Slow Food and GI system are hybrid strategies, based on market tools blended with social values, and may include new elements over time, such as the concern regarding cheese microbiodiversity. GIs respond to and foster a change in social awareness, within a general frame of increasing environmental regulations. GIs appropriated preoccupations related to the loss of CB by transforming cultural and natural resources into heritage. This phenomenon is mirrored by collective and individual voluntary measures, sometimes diverging, e.g. on the use of raw milk. Conversely, the Slow Food movement is more avant-garde and aims to lead a change of perception about CB amongst consumers and producers themselves, within an "alternative political ecology framework" (Escobar 1998). Presidia-the most successful scheme of action for Slow Food in the field of the defense of $\mathrm{CB}$ - fix a moral goal based on aesthetic and ecological elements to be followed by the whole movement, e.g. a change of paradigm toward "natural cheesemaking" avoiding starters.

However, our analysis of concrete experiences revealed common controversial issues, e.g. adoption by a limited number of actors or an exogenous knowledge leadership, generating gaps between institutional discourse on CB based on scientific knowledge with local stakeholders' practices mainly based on their set of values and tacit knowledge. The vagueness of the institutional concept has the potential to be exploited by actors, i.e. the leaders of Slow Food, the GI governing bodies, individual farmers, public institutions, traders, and allow them to unify and direct action. Despite the limitations represented by possible disconnections between the OFS actors and the biocultural resources, we conclude that focusing on $\mathrm{CB}$ can offer local actors renovated awareness, political voice and empowerment, and connection with consumers.

Future research could further investigate pernicious dynamics of the consolidation of cultural biodiversity in the marketplace (e.g. biodiversity indicators, price formation) and, in parallel, explore limits and potentials of states or social movements in the management of $\mathrm{CB}$ as a common (Ostrom 1990), in particular by looking at the generation of collective management practices in specific experiences.
Acknowledgements This work has been supported by the Agricultural Transformation by Innovation (AGTRAIN) Erasmus Mundus Joint Doctorate Programme, funded by the EACEA (Education, Audiovisual and Culture Executive Agency) of the European Commission. We also acknowledge the financial support of the University of Catania research project "Valutazione della sostenibilità dei sistemi agroalimentari locali" WP4.

Funding AGTRAIN EU Program,Università di Catania,WP4 - 'Economic assessments of the sustainability of agri-food systems' project

Open Access This article is licensed under a Creative Commons Attribution 4.0 International License, which permits use, sharing, adaptation, distribution and reproduction in any medium or format, as long as you give appropriate credit to the original author(s) and the source, provide a link to the Creative Commons licence, and indicate if changes were made. The images or other third party material in this article are included in the article's Creative Commons licence, unless indicated otherwise in a credit line to the material. If material is not included in the article's Creative Commons licence and your intended use is not permitted by statutory regulation or exceeds the permitted use, you will need to obtain permission directly from the copyright holder. To view a copy of this licence, visit http://creativecommons.org/licenses/by/4.0/.

\section{References}

Agnoletti, M., and I.D. Rotherham. 2015. Landscape and biocultural diversity. Biodiversity Conservation 24 (3): 3155-3165.

Altieri, M.A., and L. Merrick. 1987. In situ conservation of crop genetic resources through maintenance of traditional farming systems. Economic Botany 41 (1): 86-96.

Asher, D. 2016 The art of natural cheesemaking. White River Junction, VT: Chelsea Green

Aubertin, C., F. Pinton, and V. Boisvert. 2007. Les marchés de la biodiversité. Paris, FR: IRD éditions

Barnaud, C., and M. Antona. 2014. Deconstructing ecosystem services: Uncertainties and controversies around a socially constructed concept. Geoforum 56: 113-123.

Belletti, G., and A. Marescotti. 2011. Origin products, geographical indications and rural development. In Labels of origin for food, ed. E. Barham and B. Sylvander, 75-91. Wallingford, UK: CABI.

Belletti, G., A. Marescotti, and H. Vakoufaris. 2015. Linking protection of geographical indications to the environment: Evidence from the European Union olive-oil sector. Land Use Policy 48: 94-106.

Belletti, G., A. Marescotti, and J.-M. Touzard. 2017. Geographical indications, public goods, and sustainable development: The roles of actors' strategies and public policies. World Development 98: 45-57.

Bendix, R., and V.T. Hafstein. 2009. Culture and property. An Introduction. Ethnologia Europaea 39 (2): 5-10.

Bérard, L., M. Cegarra, M. Djama, S. Louafi, P. Marchenay, B. Roussel, and F. Verdeaux. 2005. Biodiversity and Local Ecological Knowledge in France. Paris, FR: CIRAD, IDDRI, IFB, and INRA.

Bérard, L., F. Casabianca, M.-C. Montel, C. Agabriel, and R. Bouche. 2016. Salers Protected Designation of Origin cheese, France. The diversity and paradox of local knowledge in geographical indications. Culture \& History Digital Journal 5(1): e006.

Bérard, L., and P. Marchenay. 2006. Local Products and Geographical Indications: Taking account of local knowledge and biodiversity. International Social Science Journal 58 (187): 109-116. 
Biénabe, E., M. Leclercq, and P. Moity-Maïzi. 2009. Le rooibos d'Afrique du Sud: Comment la biodiversité s'invite dans la construction d'une Indication Géographique. Autrepart 2: 117-134.

Blakeney, M. 2013. Geographical Indications, Traditional Knowledge, Expressions of Culture and the Protection of Cultural Products in Africa. In Extending the protection of Geographical Indications: Case studies of agricultural products in Africa, ed. M. Blakeney, et al., 132-146. New York, NY: Routledge.

Blandin, P. 2009. De la protection de la nature au pilotage de la biodiversité. Versailles, FR: Éditions Quæ.

Boisvert, V., and A. Caron. 2010. La conservation de la biodiversité: Un nouvel argument de différenciation des produits et de leur territoire d'origine. Géographie, Économie, Société 12 (3): 307-328.

Bowen, S. 2010. Embedding local places in global spaces: Geographical Indications as a territorial development strategy. Rural Sociology 75 (2): 209-243.

Bowen, S. 2015. Divided Spirits: Tequila, Mezcal, and the Politics of Production. Oakland, CA: University of California Press.

Bowen, S., and K. De Master. 2011. New rural livelihoods or museums of production? Quality food initiatives in practice. Journal of Rural Studies 27 (1): 73-82.

Bowen, S., and K. De Master. 2014. Wisconsin's "Happy Cows"? Articulating heritage and territory as new dimensions of locality. Agriculture and Human Values 31 (4): 549-562.

Bowen, S., and A.V. Zapata. 2009. Geographical indications, terroir, and socioeconomic and ecological sustainability: The case of Tequila. Journal of Rural Studies 25 (1): 108-119.

Brookfield, H. 2001. Exploring agrodiversity: Issues, cases, and methods in biodiversity conservation. New York, NY: Columbia University Press.

Brush, S.B. 1991. A farmer-based approach to conserving crop germplasm. Economic Botany 45 (2): 153-165.

Buizer, M., B. Elands, and K. Vierikko. 2016. Governing cities reflexively-The biocultural diversity concept as an alternative to ecosystem services. Environmental Science \& Policy 62: 7-13.

Carpino, S., L. Tuminello, T. Rapisarda, and G. Licitra. 2010. Piacentinu Ennese cheese: State of art. Scienza e Tecnica LattieroCasearia 61 (4): 187-217.

Carrà, G. 2005. Strategie competitive dei prodotti agroalimentari tipici. In Atti del XLII Convegno della SIDEA, Biodiversità e tipicità. Paradigmi economici e strategie competitive, Pisa, 22-24 settembre 2005, eds. SIDEA, and G. Brunori, 22-23. Milano, IT: Franco Angeli.

Casalta, E., J.-M. Sorba, M. Aigle, and J.-C. Ogier. 2009. Diversity and dynamics of the microbial community during the manufacture of Calenzana, an artisanal Corsican cheese. International Journal of Food Microbiology 133 (3): 243-251.

Castree, N. 2008. Neoliberalising nature: The logics of deregulation and reregulation. Environment and Planning A 40 (1): 131-152.

Chabrol, D., and D. Marie-Vivien, D. 2014. Geographical Indications (GIs), biodiversity and poor communities. Technical Report. Montpellier, FR: CIRAD, UNCTAD, and CFF.

CNAOL. 2018. https://www.fromages-aop.com Accessed 5 August 2018.

Curci, J. 2010. The Protection of Biodiversity and Traditional Knowledge in International law of intellectual property. Cambridge, UK: Cambridge University Press.

De Sainte-Marie, C., M. Mariani, M. Millet, C. Cerdan, and F. Casabianca. 2020. Can raw milk cheese and pasteurised milk cheese coexist? Unthinkable or never really considered? Review of Agricultural, Food and Environmental Studies 101 (2): 287-309.

Dedeurwaerdere, T. 2014. Sustainability science for strong sustainability. Cheltenham, UK: Edward Elgar.
Descola, P. 2011. L'écologie des autres: l'anthropologie et la question de la nature. Paris, FR: Editions Quæ.

Deverre, C., and De Sainte-Marie C. 2008. L'écologisation de la politique agricole européenne. Verdissement ou refondation des systèmes agro-alimentaires? Review of Agricultural and Environmental Studies 89(4): 83-104.

Dreyfus, H., and P. Rabinow. 1982. Michel Foucault: Beyond hermeneutics and structuralism. Brighton, UK: Harvester.

Durand, C., and S. Fournier. 2017. Can Geographical Indications modernize Indonesian and Vietnamese agriculture? Analyzing the role of national and local governments and producers' strategies. World Development 98: 93-104.

EC (European Commission). 2011. Our life insurance, our natural capital: An EU biodiversity strategy to 2020: Communication from the Commission to the European Parliament, the Council, the European Economic and Social Committee and the Committee of the Regions. Brussels, BE: Publications Office of the European Union.

Escobar, A. 1998. Whose knowledge, whose nature? Biodiversity, conservation, and the political ecology of social movements. Journal of Political Ecology 5 (1): 53-82.

Fallico, V., L. Tuminello, C. Pediliggieri, J. Horne, S. Carpino, and G. Licitra. 2006. Proteolysis and microstructure of Piacentinu Ennese cheese made using different farm technologies. Journal of Dairy Science 89 (1): 37-48.

Feutry, F., M. Oneca, F. Berthier, and P. Torre. 2012. Biodiversity and growth dynamics of lactic acid bacteria in artisanal PDO Ossau-Iraty cheeses made from raw ewe's milk with different starters. Food Microbiology 29 (1): 33-42.

Feutry, F., P. Torre, I. Arana, S. Garcia, F.J. Pérez Elortondo, and F. Berthier. 2016. Suitability of a new mixed-strain starter for manufacturing uncooked raw ewe's milk cheeses. Food Microbiology 56: 52-68.

Fonte, M. 2006. Slow Food's Presidia: What do small producers do with big retailers? In Between the local and the global (Research in Rural Sociology and Development 12), ed. T. Marsden and J. Murdoch, 203-240. Bingley, UK: Emerald Group Publishing Limited.

Fonte, M. 2008. Knowledge, food and place. A way of producing, a way of knowing. Sociologia Ruralis 48(3): 200-222.

Slow Food. 2015. Preserving biodiversity, preserving the planet. A document to illustrate Slow Food's position on biodiversity in Europe. https://www.fondazioneslowfood.com/wp-conte nt/uploads/2015/04/biodiversita_position_paper_ENG.pdf Accessed 26 May 2018.

Slow Food. 2017. Slow Cheese. https://www.slowfood.com/what-wedo/themes/slow-cheese/. Accessed 26 May 2018.

Foucault, M. 1971. L'ordre du discours. Paris, FR: Gallimard.

Foucault, M. 1980. The history of sexuality, vol. I. New York, NY: Pantheon Books.

Foucault, M. 1981. Omnes et Singulatim: Towards a criticism of 'Political Reason.' In The Tanner Lectures on Human Values II, ed. S.M. McMurrin, 223-254. Cambridge, UK: Cambridge University Press.

Foucault, M. 1991. Governmentality. In The Foucault effect: Studies in governmentality, ed. G. Burchell, C. Gordon, and P. Burchell, 87-104. Chicago, IL: University of Chicago Press.

Foyer, J. 2010. Il était une fois la bio-révolution. Nature et savoirs dans la modernité globale. Paris, FR: Presses universitaires de France.

Frétin, M., B. Martin, E. Rifa, I. Verdier-Metz, D. Pomiès, A. Ferlay, M.-C. Montel, and C. Delbès. 2018. Bacterial community assembly from cow teat skin to ripened cheeses is influenced by grazing systems. Nature 8 (1): 1-11.

Giovannucci, D., T. E. Josling, W. Kerr, B. O'Connor, and M. T. Yeung. 2009. Guide to Geographical Indications: Linking 
products and their origins. Geneva, $\mathrm{CH}$ : International Trade Centre.

Goodman, D., and E.M. DuPuis. 2002. Knowing food and growing food: Beyond the production-consumption debate in the sociology of agriculture. Sociologia Ruralis 42 (1): 5-22.

Graddy, T.G. 2013. Regarding biocultural heritage: In situ political ecology of agricultural biodiversity in the Peruvian Andes. Agriculture and Human Values 30 (4): 587-604.

Grasseni, C. 2017. The heritage arena: Reinventing cheese in the Italian Alps. New York, NY: Berghahn Books.

Grasseni, C. 2011. Re-inventing food: Alpine cheese in the age of global heritage. Anthropology of Food 8.

Gustafsson, K.M. 2013. Environmental discourses and biodiversity: The construction of a storyline in understanding and managing an environmental issue. Journal of Integrative Environmental Sciences 10 (1): 39-54.

Guthman, J. 2004. Back to the land: The paradox of organic food standards. Environment and Planning A 36: 511-528.

Guthman, J. 2007. The Polanyian way? Voluntary food labels as neoliberal governance. Antipode 39 (3): 456-478

Hafstein, V. T., and M. Skrydstrup. 2017. Heritage vs. property. In The Routledge Companion to Cultural Property, eds. J. Anderson, and H. Geismar. London, UK: Routledge.

Holmes, G. 2015. Markets, nature, neoliberalism, and conservation through private protected areas in southern Chile. Environment and Planning A 47 (4): 850-866.

Isla, A., and F. Wallet. 2010. Innovations institutionnelles dans les dispositifs d'Indications Géographiques et intégration des principes de développement durable. Revue De L'economie Méridionale 4 (225-226): 9-35.

King, A.B., and P.B. Eyzaguirre. 1999. Intellectual property rights and agricultural biodiversity: Literature addressing the suitability of IPR for the protection of indigenous resources. Agriculture and Human Values 16 (1): 41-49.

Lacy, W.B. 1994. Biodiversity, cultural diversity, and food equity. Agriculture and Human Values 11 (1): 3-9.

Latour, B. 1987. The pasteurization of French society. Cambridge, MA: MIT Press.

Leitch, A. 2003. Slow food and the politics of pork fat: Italian food and European identity. Ethnos 68 (4): 437-462.

Licitra, G., and S. Carpino. 2014. The microfloras and sensory profiles of selected protected designation of origin Italian cheeses. In Cheese and Microbes, ed. C.W. Donnelly, 151-165. Herndon, VA: American Society of Microbiology.

Liverman, D. 2004. Who governs, at what scale and at what price? Geography, environmental governance, and the commodification of nature. Annals of the Association of American Geographers 94 (4): 734-738.

Lortal, S., A. Di Blasi, M.-N. Madec, C. Pediliggieri, L. Tuminello, G. Tanguy, J. Fauquant, et al. 2009. Tina wooden vat biofilm: A safe and highly efficient lactic acid bacteria delivering system in PDO Ragusano cheese-making. International Journal of Food Microbiology 132 (1): 1-8.

Lortal, S., G. Licitra, and F. Valence. 2014. Wooden tools: Reservoirs of microbial biodiversity in traditional cheesemaking. In Cheese and Microbes, ed. C.W. Donnelly, 167-176. Herndon, VA: American Society of Microbiology.

Lotti, A. 2010. The commoditization of products and taste: Slow food and the conservation of agrobiodiversity. Agriculture and Human Values 27 (1): 71-83.

MacDonald, K.I. 2013. The morality of cheese: A paradox of defensive localism in a transnational cultural economy. Geoforum 44: 93-102.

Marie-Vivien, D., C.A. Garcia, C.G. Kushalappa, and P. Vaast. 2014. Trademarks, geographical indications and environmental labelling to promote biodiversity: The case of agroforestry coffee in India. Development Policy Review 32 (4): 379-398.

Marsden, T., and E. Smith. 2005. Ecological entrepreneurship: Sustainable development in local communities through quality food production and local branding. Geoforum 36 (4): 440-451.

May, S. 2013. Cheese, commons and commerce: On the politics and practices of branding regional food. Ethnologia Europaea 43 (2): 62-77.

McLaughlin, A., and P. Mineau. 1995. The impact of agricultural practices on biodiversity. Agriculture, Ecosystems \& Environment 55 (3): 201-212.

Miele, M., and J., Murdoch. 2002. The practical aesthetics of traditional cuisines: Slow food in Tuscany. Sociologia Ruralis 42 (4): 312-328.

Montel, M.-C., S. Buchin, A. Mallet, C. Delbes-Paus, D.A. Vuitton, N. Desmasures, and F. Berthier. 2014. Traditional cheeses: Rich and diverse microbiota with associated benefits. International Journal of Food Microbiology 177: 136-154.

Montenegro de Wit, M. 2016. Are we losing diversity? Navigating ecological, political, and epistemic dimensions of agrobiodiversity conservation. Agriculture and Human Values 33 (3): 625-640.

Morris, C., and J. Kirwan. 2011. Ecological embeddedness: An interrogation and refinement of the concept within the context of alternative food networks in the UK. Journal of Rural Studies 27 (3): 322-330.

Murdoch, J., T. Marsden, and J. Banks. 2000. Quality, nature, and embeddedness: Some theoretical considerations in the context of the food sector. Economic Geography 76 (2): 107-125.

Nazarea, V.D. 2005. Heirloom seeds and their keepers: Marginality and memory in the conservation of biological diversity. Tucson, AZ: University of Arizona Press.

Nazarea, V.D., R.E. Rhoades, and J.E. Andrews-Swan, eds. 2013. Seeds of resistance, seeds of hope: Place and agency in the conservation of biodiversity. Tucson, AZ: University of Arizona Press.

Orlove, B.S., and S.B. Brush. 1996. Anthropology and the conservation of biodiversity. Annual Review of Anthropology 25 (1): 329-352.

Ostrom, E. 1990. Governing the Commons: The evolution of institutions for collective action. Cambridge, UK: Cambridge University Press.

Paxson, H. 2012. The life of cheese: Crafting food and value in America. Berkeley, CA: University of California Press.

Pecorari, M., G. Gambini, A. Pecorari, F. Masotti, J. Hogenboom, L. Pellegrino, S. Ghidini, M. Malacarne, and P. Mariani. 2009. L'utilizzo di caldaie di rame o di acciaio: Effetti sulla tecnologia e sulle caratteristiche qualitative del Parmigiano-Reggiano. Scienza e Tecnica Lattiero-Casearia 60 (2): 97-118.

Percival, B., and F. Percival. 2017. Reinventing the Wheel: Milk, Microbes, and the Fight for Real Cheese, vol. 65. Berkley, CA: University of California Press.

Plantureux, S., A. Peeters, and D. McCracken. 2005. Biodiversity in intensive grasslands: Effet of management, improvement and challenges. Agronomy Research 3 (2): 153-164.

Plieninger, T., R. Kohsaka, C. Bieling, S. Hashimoto, C. Kamiyama, T. Kizos, M. Penker, et al. 2018. Fostering biocultural diversity in landscapes through place-based food networks: A 'solution scan' of European and Japanese models. Sustainability Science 13 (1): 219-233.

Rai, V.R., and J.A. Bai. 2015. Beneficial microbes in fermented and functional foods. Boca Raton, FL: CRC Press.

Roussel, B., and F. Verdeaux. 2007. Natural patrimony and local communities in Ethiopia: Advantages and limitations of a system of Geographical Indications. Africa 77 (1): 130-150.

Santilli, J. 2011. Agrobiodiversity and the law: Regulating genetic resources, food security and cultural diversity. London, UK: Earthscan. 
Scintu, M.F., and G. Piredda. 2007. Typicity and biodiversity of goat and sheep milk products. Small Ruminant Research 68: 221-231.

Shiva, V. 1993. Monocultures of the mind: Perspectives on biodiversity and biotechnology. London, UK: Zed Books.

Siniscalchi, V. 2013. Environment, regulation and the moral economy of food in the Slow Food movement. Journal of Political Ecology 20 (1): 295-305.

Slow Food Foundation for Biodiversity (SFFB). 2018. https://www. fondazioneslowfood.com/en/our-themes/biodiversity/. Accessed 26 May 2018.

Steffen, W., K. Richardson, J. Rockström, S.E. Cornell, I. Fetzer, E.M. Bennett, R. Biggs, et al. 2015. Planetary boundaries: Guiding human development on a changing planet. Science 347 (6223): 1259855 .

Takacs, D. 1996. The idea of biodiversity: Philosophies of paradise. Baltimore, MD: Johns Hopkins University Press.

Thévenod-Mottet, E. 2010. Geographical indications and biodiversity. In Agriculture, biodiversity and markets, ed. S. Lockie and D. Carpenter, 201-212. Washington, DC: Earthscan.

Thomas, F. 2015. Le pouvoir de la biodiversité. Introduction. In $\mathrm{Le}$ pouvoir de la biodiversité: Néolibéralisation de la nature dans les pays émergents, eds. F. Thomas, and V. Boisvert. Paris, FR: Editions Quae, IRD.

Trubek, A.B. 2008. The taste of place: A cultural journey into terroir. Berkley and Los Angeles, CA: University of California Press.

Van Overwalle, G. 2005. Protecting and sharing biodiversity and traditional knowledge: Holder and user tools. Ecological Economics 53 (4): 585-607.

Van Caenegem, W., and M. Taylor. 2017. Real deal or no deal? A comparative analysis of raw milk cheese regulation in Australia and France. International Journal of Rural Law and Policy 1 (1): $1-15$.

Vandecandelaere, E., F. Arfini, G. Belletti, and A. Marescotti. 2009. Linking people, places and products. Rome, IT: FAO/SINERGI.

Vitrolles, D. 2011. When Geographical Indication conflicts with food heritage protection. The case of Serrano cheese from Rio Grande do Sul, Brazil. Anthropology of Food 8

West, H.G. 2008. Food fears and raw-milk cheese. Appetite 51 (1): 25-29.
West, H.G., and N. Domingos. 2012. Gourmandizing poverty food: The Serpa cheese Slow Food Presidium. Journal of Agrarian Change 12 (1): 120-143.

Publisher's Note Springer Nature remains neutral with regard to jurisdictional claims in published maps and institutional affiliations.

Mariagiulia Mariani is an independent researcher in anthropology of food and currently collaborates with CIRAD, University of Catania, the French National Research Institute for Agriculture, Food and Environment (INRAE), and the CGIAR. She obtained a joint $\mathrm{PhD}$ in Geography (Montpellier SupAgro) and in Agricultural, Food and Environmental Science (University of Catania), and a MA in Anthropology of Food (SOAS, University of London). Her interdisciplinary research interests cover labeling systems (e.g. Geographical Indications) and alternative agricultural practices, and namely artisan cheese systems. Some of her work was recently published in World Development (2017) and the Sociologia Ruralis (2020).

Claire Cerdan is a researcher at CIRAD, the French Agricultural Research Centre for International Development. Her research focuses on localized Agrifood Systems in Brazil and Réunion.

Iuri Peri is Professor at the University of Catania, Department of Agriculture, Food and Environment (Di3A), and Director of the Master in Viticulture, Oenology and Enomarketing. His expertise focuses on qualitative and quantitative studies on EU agri-food policies, multilevel governance and rural development policies, quality agri-food production, food security, sustainability, and the bioeconomy. He has collaborated with many international institutions (EU-DGSANCO, OECD, CIHEAM) and he is involved in several international study and research programs, such as AgriMundus-Agrinatura, AgTraIn, Chaire Unesco-ADM, Tempus -QESAMed, ENPICBC-LactiMed. 